\title{
AN ANALYSIS ON THE IMPLEMENTATION OF THE INTEGRATED GUIDANCE POST (POSBINDU) ACTIVITIES FOR NON-COMMUNICABLE DISEASES
}

\section{AT BOGOR CITY IN 2018}

\author{
*Alfiyah, ** Pujiyanto \\ * Health Policy and Administration, Faculty of Public Health, Universitas Indonesia, Kampus Depok, Jawa Barat, 16425, \\ Indonesia \\ ** Health Policy and Administration, Faculty of Public Health, Universitas Indonesia, Kampus Depok, Jawa Barat, 16425, \\ Indonesia
}

Email : alpipiya1414@gmail.com

\begin{abstract}
One of the endeavors that the government has done to prevent and control non-communicable diseases (NCD) by increasing community participation in the early detection of NCDs is the NCD Integrated Guidance Post (Posbindu). However, in 2017, only $12.96 \%$ of the residents in Bogor City accessed it. This meant that the $30 \%$ target was not reached. The in this study, we researched the implementation of the NCD Posbindu at Bogor City. Data was gathered through in-depth interviews, Focus Group Discussion (FGD), documentary research, and observations. Eleven informants was interviewed and 24 informants was involved in the FGD. Two NCD Posbindus was observed at Mekarwangi and Cipaku Public Health Centers (PHC). We discovered that the standards and policies have supported the program, but not all the informants were aware of the targets of the program; there were also problems in the number and abilities of the human resources involved, ineffective communication between the cadres, in the coordination between the cadres, and lack of support from local public figures. The program had adequate funding from the regional budget, the Operational Health Aid Funds, and donations from the community. Although more funds are necessary for the promotion and prevention part of the program. We recommend that new cadres are recruited and trained, and that a reward system is used to provide motivation for the cadres.
\end{abstract}

Keywords: Health Policy Implementation, NCD Posbindu, Non-communicable Diseases.

Abstrak. Salah satu upaya pemerintah untuk mencegah dan mengendalikan penyakit tidak menular melalui peningkatan peran serta masyarakat dalam deteksi dini faktor risiko penyakit tidak menular adalah melalui Pos Pembinaan Terpadu (Posbindu) Penyakit Tidak Menular (PTM). Namun, pada tahun 2017 cakupan kunjungan masyarakat ke Posbindu PTM di Kota Bogor hanya sebesar 12,96\%. Ini berarti target yang ditetapkan (30\%) belum tercapai. Penelitian ini bertujuan untuk mengetahui bagaimana implementasi kegiatan Posbindu PTM di Kota Bogor. Metode yang digunakan adalah wawancara mendalam, Focus Group Discussion (FGD), telaah dokumen dan observasi. Informan penelitian terdiri dari 11 informan wawancara mendalam dan 24 informan FGD. Observasi dilakukan di 2 Posbindu PTM di Puskesmas Mekarwangi dan Puskesmas Cipaku. Peneliti menemukan bahwa standar dan kebijakan yang ada telah mendukung program, tetapi belum semиa informan mengetahui siapa target program, selain itu juga terdapat permasalahan dalam jumlah dan kemampuan kader, komunikasi yang tidak efektif antar kader, koordinasi antar kader, dan kurangnya dukungan dari tokoh masyarakat local. Pendanaan program tidak mengalami masalah, karena dana program berasal dari APBD, dana Bantuan Operasional Kesehatan, dan sumbangan masyarakat. Walaupun masih membutuhkan pendanaan lebih lanjut untuk promosi dan pencegahan. Peneliti merekomendasikan dilaksanakannya pembaharuan informasi dan pelatihan yang berkala untuk para kader, perekrutan kader baru, pemberian reward atau pemilihan kader teladan dan Posbindu PTM terbaik, peningkatan kerja sama lintas sektor lembaga pendidikan, pemerintah dan swasta.

Kata kunci: Implementasi Kebijakan Kesehatan, Posbindu PTM, Penyakit Tidak Menular.

\section{INTRODUCTION}

According to the 2007 Basic Health Research (Riskesdas) and a survey by the Ministry of Health Research and Development Agency (Litbangkes) in 2014 , the most common cause of death was noncommunicable diseases, such as stroke, heart diseases, diabetes, hypertension, and its complications. Moreover, the numbers continues to increase. In 2007, $0.6 \%$ of patients at the healthcare facilities were diagnosed with stroke. In 2013, this number increased to $0.7 \%$. Asthma increased to $4.5 \%$ from $1.9 \%$, diabetes increased to $1.5 \%$ from $0.7 \%$, and hypertension increased to $9.4 \%$ from $7.2 \%{ }^{1}$ 
This increase was also influenced by the increase of risky behaviors, such as smoking, lack of physical exercise, consumption of high salt foods and high fat foods. According to the 2013 Riskesdas, 36.3\% of people in Indonesia were active smokers, $68.8 \%$ were men. $26.1 \%$ of people were physically inactive, $26.2 \%$ consumed foods high in salt, and $40.7 \%$ consumed foods high infat. ${ }^{1}$ In Bogor City, the $32.0 \%$ of residents aged $\geq 10$ years old were active smokers, $36.9 \%$ of residents lacked physical exercise, $47.1 \%$ consumed foods high in fat more than once a day, and $32.5 \%$ consumed salty foods more than once a day. ${ }^{2}$ If this is done every day, then the risk for contracting noncommunicable diseases will rise.

Therefore, the Ministry of Health endeavors to increase public participation and empowerment through the NCD Posbindu. The activities in the Posbindu is supervised by the Puskesmas and it focuses on the prevention and control of NCDs. Prevention activities include health promotion, screening, and monitoring of the risk factors. While control is by finding the NCD cases as early as possible and providing immediate treatment. $^{3}$

The NCD Posbindu at Bogor city began in 2009. The city was also appointed as the location of the pilot project for the early detection of cardiovascular diseases risk factors. However, the total visitation in 2017 was only $12.96 \%$, which is far from the $30 \%$ target. According to the 2017 report from the Bogor City Health Office, the total screenings for the risk factors of NCDs was also below target (12.96\%), just as low as the cervical cancer screening totals $(10.55 \%)$ and breast lumps $(9.8 \%)$ in $2016 .^{2}$ The low visitation number to the Posbindu and the low screening numbers indicates that the Community Empowered Health Units (UKBM) was rarely used, although it was effective for the prevention of NCDs. ${ }^{4}$

In this research we gathered the detailed information on the activities involved in the implementation of the NCD Posbindu from the standards and the goals of the policies, resources, communication between implementer, characteristics of the implementing body, the implementers' attitude, and the social, economy, and political aspects that influence it.

\section{METHODS}

This qualitative study was done in Bogor City between May and July 2018. Data was gathered from in-depth interviews, Focus Group Discussion (FGD), documentary research, and observation. There were 11 informants for the in-depth interviews; they were the stakeholders of the program at the Health Office, Puskesmas, and sub-districts (kelurahan). As for the FGD, 24 informants were involved, they were cadres from the NCD Posbindus in Puskesmas Mekarwangi and Puskesmas Cipaku.

\section{RESULTS AND DISCUSSION}

Based on the research concept of the Van Meter and Van Horn theory on analysis of policy implementation, we evaluated the following aspects. ${ }^{11}$

\section{Standards and Goals of the Policy}

We discovered that all the informants are aware on what are the guidelines for the activities performed in the NCD Posbindu. The policies that support these activities are the Minister of Health Regulation no. $71 / 2015$ on the Management of Non-communicable Diseases, ${ }^{5}$ Minister of Health Regulation no. 5/2017 on the Action Plan for Managing Non-communicable Diseases, ${ }^{6}$ Minister of Health Regulation no. 43/2016 on the Minimal Standards for Healthcare, ${ }^{7}$ Bogor Mayor Regulation no. 48/2017 on the Bogor City Health Living Movement Community. ${ }^{8}$ The regulations stated that the community must be involved and empowered in the management and prevention of NCDs through the Posbindu. The activities of this Posbindu include early detection and monitoring of risk factors of NCDs and early management. All the informants were aware of the goals of the implementation of the Posbindu activities, but not all were aware of the age group targeted. Therefore, most cadres focuses only on the elderly. This will influence the success of the activities, as what was found by Fauzia in 2013, residents aged between 15-44 years old rarely use the Posbindu. ${ }^{9}$ To solve this, all the implementers, especially the cadres must be informed on the age target of the activities through trainings and seminars.

\section{Resources}

According to Miranti, the quality and quantity of human resources influences the program's success. ${ }^{10}$ The human resources involved in the activities of the NCD Posbindu were a Puskesmas staff (a nurse) and cadres from the local community. The program holders at Puskesmas Mekarwangi and Cipaku was competent, because they have the educational background and the capabilities to perform health examinations and counseling to the community. However, the quantity and quality of the cadres were inadequate, ideally each Posbindu has 5 cadres and they would be able to perform the activities independently. We discovered that some Posbindus had less than five cadres, it all depends on the activeness and the motivation of the cadre, and the cadres mostly were only capable of documenting, measuring height, weight, and abdominal circumference, while the Puskesmas staff did Body Mass Index (BMI) calculations and consultations. Since, the number and capabilities of the cadres plays a large role in the success of the posbindu, the Puskesmas 
should collaborate with the local government to recruit and train new cadres, since the current cadres are elderly and have limited capabilities.

The Puskesmas staff were well involved in the Posbindu activities. They were present at each activity and provided health examinations and counseling to all the participants. But the cadres only recorded the results of the measurement, the Puskesmas staff were the ones performing the health examinations and counseling. The cadre's competence and motivation is vital to the success of the activities, as stated by Winarno, the success of a policy is largely determined by the capabilities of the people involved in its implementation. ${ }^{11}$ Annisa also found that knowledgeable cadres play a large role in the usage of elderly Posbindu in the community. ${ }^{12}$

The funding for the activities were from the regional budget and the Health Operational Fund (BOK). The funds from the regional budget was used to revitalize the Posbindu, while the funds from the BOK was used to procure blood sugar and cholesterol testing strips. Because of the limited funds, the cadre had to be smart in using the funds and to fund new ways to produce more funds, because the UKBM was meant to increase community participation and independence. Which according to Parinduri, was successfully done at Puskesmas Glugur Darat North Sumatera, where they obtained funds by collaborating with the private sector through their Corporate Social Responsibility programs. ${ }^{13} \mathrm{We}$ discovered that there was some donations from the local community for the purchase of weighing equipment.

As for facilities, some used a resident's house and some used the Posyandu building for the activities. Other facilities were tables, weight, height, and abdominal circumference measuring tools. The Puskesmas staff would bring the sphygmomanometer and the blood sugar and cholesterol measurement tool. There were adequate facilities to support the activities, but the promotion and prevention media aids for the cadres to educate the community on NCDs was not adequate. For example, not all Posbindu participants had their own NCD risk factor Health Cards (Kartu Menuju Sehat Faktor Risiko PTM or KMS FR-PTM). Although Setyawan stated that physical resources supports the work of the health staff in providing optimal healthcare at the Puskesmas. ${ }^{14}$ To manage the lack of media aids, the cadres must actively inform the Puskesmas and Health Office on what facilities that they need, such as KMS FR-PTM and media aids for promotion at the NCD Posbindu (brochures, leaflets, posters).

\section{Communication between Implementers}

Communication is evaluated based on the process of information distribution, and the types and frequency of information distributed. ${ }^{11}$ Once a month, the
Puskesmas staff performs socialization, as according to the Posbindu NCD schedule. The information conveyed are about the future schedules and health examinations to maintain the health of the community. However, the implementation was ineffective. This was because the socialization was done the day before the activity, and it was announced to the community (by the cadres) during the morning before the activities through WhatsApp (WA) groups, musholas, and doorto-door. The activities also were done during work hours, therefore the working-age community and school-age community cannot participate. The cadres also were not aware on which were the age groups targeted, and only targeted the elderly and only the same people attended. Therefore, the Puskesmas must collaborate with the Schools, Campuses, and Government Institutions to be able to perform NCD Posbindu activities at those areas, to gather more participants.

\section{The Characteristics of the Implementing Organizations}

We discovered that there were collaborations between the implementers and other related organizations, such as the kelurahan, cross program cooperation within the Health Office and the Puskesmas between the Health Promotion Division, School Health Unit, Nutrition Division, and the Elderly Division. This collaboration accomplished, although not that effective, especially on cross sector support. Because the local public figures were notably absent in the activities, there were even Posbindu that has not been visited at all by the Kelurahan officials. The participation of public figures would create a positive image and an image that the program was important to their area. This might encourage more people to visit the Posbindu. This was confirmed by Melita, which found that support from the family and public figures correlated to the visitation rate to the Elderly Posbindu at Puskesmas Kelurahan Bintara Bekasi. ${ }^{15}$ Therefore, the local Kelurahan should increase monitoring to each Posbindu in their area and collaborate with the Puskesmas.

The coordination/authority delegation process of the NCD Posbindu activities should be done in stages, from the Health Office, to the Puskesmas, then the Cadres. However, the coordination process between cadres was unclear. The task distribution was also not uniform, some had permanent tasks and some were rotated, and who is responsible for what was also unclear. This might cause misunderstandings in the recording or measuring process, if the cadres were inactive and did not have the same understanding. Since, according to Lutfy dkk, a clear task division between cadres will influence the success of a policy, ${ }^{16}$ an established, clear and written task division for each cadre is necessary. The Puskesmas, as the supervisor for the area, must ensure that all the cadres understand their tasks and is skillful in performing it. 


\section{The Disposition of the Implementers}

According to Wahab, disposition is the traits and characteristics that the implementer has. These are their commitment, honesty, and independence. When the implementers have a good disposition, they would be able to implement the policy just as intended by the policy maker. ${ }^{17} \mathrm{We}$ discovered that during the activities of the NCD posbindu, the puskesmas staff were motivated and had great attitudes when they monitored and communicated with the cadres during the activities. The staff also assisted by performing health examinations and providing counseling for blood pressure, blood sugar and cholesterol levels to the participants.

However, the motivation and the attitudes of the cadres vary from each cadre to cadre. Some were highly motivated and assisted the staff by measuring the height and weight of the patients. Some only recorded the results, some only looked around and helped when they were ordered, and some were completely unmotivated that they did not come to the event at all. This meant that they were not supportive to the program, because some cadres were not active during the activities. The cadres also did not play a large role in the posbindu, the puskesmas staff performed most of the activities. For example, counseling were provided by the puskesmas staff. The cadres also did not have enough confidence and always asked the puskesmas staff. To increase the cadre's motivation and improve their attitudes, perhaps a reward system can be implemented, such as selecting the "best cadre of the month".

\section{Social, Economic, and Political Support}

Social, economic, and political support influences the success of a policy. In her research, Parinduri discovered that the support and participation of the local neighborhood leaders, religious figures, and donors increased the cadres' motivation in managing the posbindu. ${ }^{13}$ It would also help in spreading information on the activities to the community through religious gatherings and neighborhood meetings. However, we discovered that there was not enough support from this sector, the local public figures do not always attend the activities at the posbindu. The Subdistrict government can also help by providing a location for the posbindus in their area.

As for political support, there was support from the local government, the local Mayor's Office, that issued Decree No.48/2017 on Healthy Community Movement in Bogor City. ${ }^{8}$ This regulation stated that the cost for treatment at the posbindus are free and it also regulated how the activities should be implemented. Although there were some posbindus that collected donations from participants.

\section{Implementation of the NCD Posbindu Activities}

The Posbindu activities at Bogor City were routinely done once a month. However, the implementation did not completely adhere to the 2012 Technical Guidelines of the NCD Posbindu from the Ministry of Health. ${ }^{18}$ We discovered that there were several activities or steps that were not done. For example, during the first stage, not all the results written in the KMS FR-PTM was copied into the ledger. The cadre will write the name and age of the participant, and then the participant will be measured. However, not all the results of the examination determined by the guidelines was written in the card or ledger, only the height, weight, blood pressure, blood sugar and cholesterol levels were recorded. The card that the participants have also do not have a monitoring sheet, so the progress of the participant each month was not readily visible.

In the second stage, the cadres did not perform the interviews to identify the risk factors, the puskesmas staff performs it during the blood pressure measurement. The cadres also did not calculate the participants' BMI, although it is an important indicator on whether or not someone was obese or not.

While in the fourth stage, the participant's blood sugar and cholesterol were not routinely examined at the posbindu, only their blood pressure was. Any participants with positive risk factors would be referred to the puskesmas for further examinations. This might be caused by the limited funds that each posbindu has, which made them unable to perform routine blood examinations. By referring the participants to the puskesmas, it negates the need to purchase the examination strips.

In the fifth stage, although the puskesmas staff has identified the risk factors and performed the follow-up procedures, the cadres failed to provide health counseling. This might because the cadres were elderly (usually pensioners) and they have limited capabilities. Therefore, just as mentioned previously, new and younger cadres must be recruited and trained. Hopefully this would increase the coverage of the program.

\section{CONCLUSIONS}

We conclude that although the implementers of this program somewhat understand and support it, they still do not completely understand who the targets were. There were also problems such as the need for more cadres with better capabilities, lack of funding, need for more promotion and prevention media aids, and in the communication between the implementers and cross sectors. Although the motivation, attitude, and performance of the puskesmas staff was good, it was 
not so with the cadres. In addition there were problems in the implementation of the program, where not all the steps/stages written in the 2012 technical guidelines were performed. These problems might be solved if the cadres were more trained and new cadres were recruited. To do this, more support from the local and national stakeholders is necessary, since it would require new regulations and funding.

\section{REFERENCES}

1. Ministry of Health, republic of Indonesia. Riset Kesehatan Dasar. Department of Health Research and Development Agency, Republic of Indonesia. Department of Health. Jakarta, 2013.

2. Bogor City Health Office (BCHO). Laporan Seksi Pencegahan dan Pengendalian Penyakit Tidak Menular Dinas Kesehatan Kota Bogor Tahun 2017. BCHO. Bogor, 2017.

3. Ministry of Health, Republic of Indonesia. PTM Pencegahan dan Pengendalian Penyakit Tidak Menular di Indonesia. Ministry of Health. Jakarta, 2016.

4. Olsen J, Nøhr EA, Thomsen RW, and Støvring H. Non-communicable disease epidemic: epidemiology in action (EuroEpi 2013 and NordicEpi 2013) Aarhus, Denmark from 11 August to 14 August 2013. European Journal of Epidemiology 2013; 28: S1-S270.

5. Ministry of Health, Republic of Indonesia. Minister of Health Regulation No. 71/2015 on the Management of Non-Communicable Diseases. State Secretariat. Jakarta, 2015.

6. Ministry of Health, Republic of Indonesia. Minister of Health Regulation No. 5/2017 on the Action Plan for the Management of Non-Communicable Diseases. State Secretariat. Jakarta, 2017.

7. Ministry of Health, Republic of Indonesia. Minister of Health Regulation No. 43/2016 on the Minimal Healthcare Standards. State Secretariat. Jakarta, 2016.

8. The Bogor Regency Mayor's Office. Mayors' Regulation no. 48/2017 on Healthy Community Movement in Bogor City. Bogor Regency Mayor's Office. Bogor, 2017.

9. Fauzia. Analisis Pemanfataan Pos Pembinaan
Terpadu Penyakit Tidak Menular di Wilayah Puskesmas Warung Jambu Kota Bogor Tahun 2013. Thesis Universitas Indonesia. Depok, 2013.

10. Miranti M. Analisis implementasi integrasi layanan pencegahan penularan HIV dari ibu ke anak (PPIA) ke layanan antenatal di kota Depok tahun 2017. Universitas Indonesia. Depok, 2017.

11. Winarno B. Kebijakan Publik: Teori dan Proses. Penerbit Media Pressindo. Jakarta, 2007.

12. Anisa R. Analisis Peran Kader Dalam Pemanfaatan Posbindu Lansia di Wilayah Kerja Puskesmas Bantar Gebang, Bekasi Tahun 2014. Tesis. Universitas Indonesia. Depok, 2014.

13. Parinduri SK. Faktor Manajemen, Komunikasi, Kemitraan, dan Inovasi dalam Pelaksanaan NCD Posbindu di Kelurahan Gunung Batu Kota Bogor Tahun 2017. Thesis, Universitas Indonesia. Depok, 2017.

14. Setyawan. Manajemen Sumber Daya Manusia Strategis: Repositioning Peran, Perilaku Plus Kompetensi Serta Peran SDM Strategi. Amara Books. Yogyakarta, 2002.

15. Melita. Faktor-Faktor yang Berhubungan dengan Kunjungan Lansia ke Posbindu Lansia di Wilayah Kerja Puskesmas Kelurahan Bintara Kota Bekasi Tahun 2017. Thesis, Universitas Indonesia. Depok, 2017.

16. Pranandari LL, Arso SP, Fatmasari EY. Analisis Implementasi Program Pos Pembinaan Terpadu Penyakit Tidak Menular (NCD Posbindu) Di Kecamatan Banguntapan Kabupaten Bantul. Jurnal Fakultas Kesehatan Masyarakat Universitas Diponegoro. Semarang, 2017.

17. Wahab SA. Analisis Kebijakan Dari Formulasi Penyusunan Model Implementasi Kebijaksanaan Publik. Kedus. Bumi Aksara. Jakarta, 2017.

18. Ministry of Health, Republic of Indonesia. Petunjuk Teknis Pos Pembinaan Terpadu Penyakit Tidak Menular (Posbindu PTM). Ministry of Health. Jakarta, 2012. 